\title{
DISLOCATIONS OF THE CERVICAL SPINE: CLOSED REDUCTION UNDER ANAESTHESIA
}

\author{
By Pieter J. Kleyn, F.R.C.S. (ED) \\ Principal Orthopaedic Surgeon, Spinal Cord Injuries Centre, Conradie Hospital, \\ Pinelands, 7405 Cape Town, South Africa.
}

Summary. This paper reviews IOI patients with dislocations and fracturedislocations of the cervical spine with neurological involvement, treated by closed reduction under anaesthesia. All were admitted to a specialised unit where early accurate diagnosis was followed by the application of Crutchfield tongs and an early attempt at closed reduction.

Of the IOI patients so treated, 82 were fully reduced. Partial reduction was obtained in six. Open reduction and posterior fusion was performed on four patients following failed closed reduction. Open reduction was not attempted in 9 patients because of their poor general condition. Twenty three patients had delayed spinal fusion because of instability demonstrated radiologically at between 6 weeks and 12 weeks.

Of the 56 patients with complete lesions, five showed major neurological recovery after 6 months, and there were ro deaths at periods from 4 to 25 days after injury. Of the 45 patients with incomplete lesions, six made a full clinical recovery, 28 made major recovery, and there were three deaths from 9 to I 4 days after injury.

Our results lead us to believe that the method is safe and reliable, even in patients received over 24 hours after the injury.

Key words: Fracture-dislocations of cervical spine; Unilateral locked facet dislocation; Bilateral locked facet dislocation; Closed reduction under anaesthesia.

\section{Introduction}

THERE is as yet no unanimity on the management of cervical spine dislocations with neurological involvement. Guttmann (I973) advocated postural reduction. By contrast skeletal skull traction (Crutchfield, I954; and Key, I975) enjoys widespread support today; but closed reduction under anaesthesia has been advocated by Burke and Berryman, (I97I), and by Evans (1983). The management of dislocation of the cervical spine with neurological damage has evolved gradually at the Spinal Cord Injuries Centre, Conradie Hospital since I963. This paper will describe the method of closed reduction employed today. A one-year follow-up of IOI patients will be presented.

The treatment of dislocations and fracture-dislocations of the cervical spine is bedevilled by the confusion that exists regarding the meaning of the terms dislocation, subluxation and locked facets. Sher (I980) has recommended that the terminology should be clarified by referring to vertebral body displacement as 'listhesis' or 'retrolisthesis' and to apophyseal joint displacement as 'dislocation' and 'subluxation'.

In this paper, Sher's definitions will be employed. Thus, Figure I reveals listhesis of $\mathrm{C}_{5}$ on $\mathrm{C}_{6}$ with dislocation of the apophyseal joints. Bilateral interlocking of the articular facets is present. Similarly Figure 


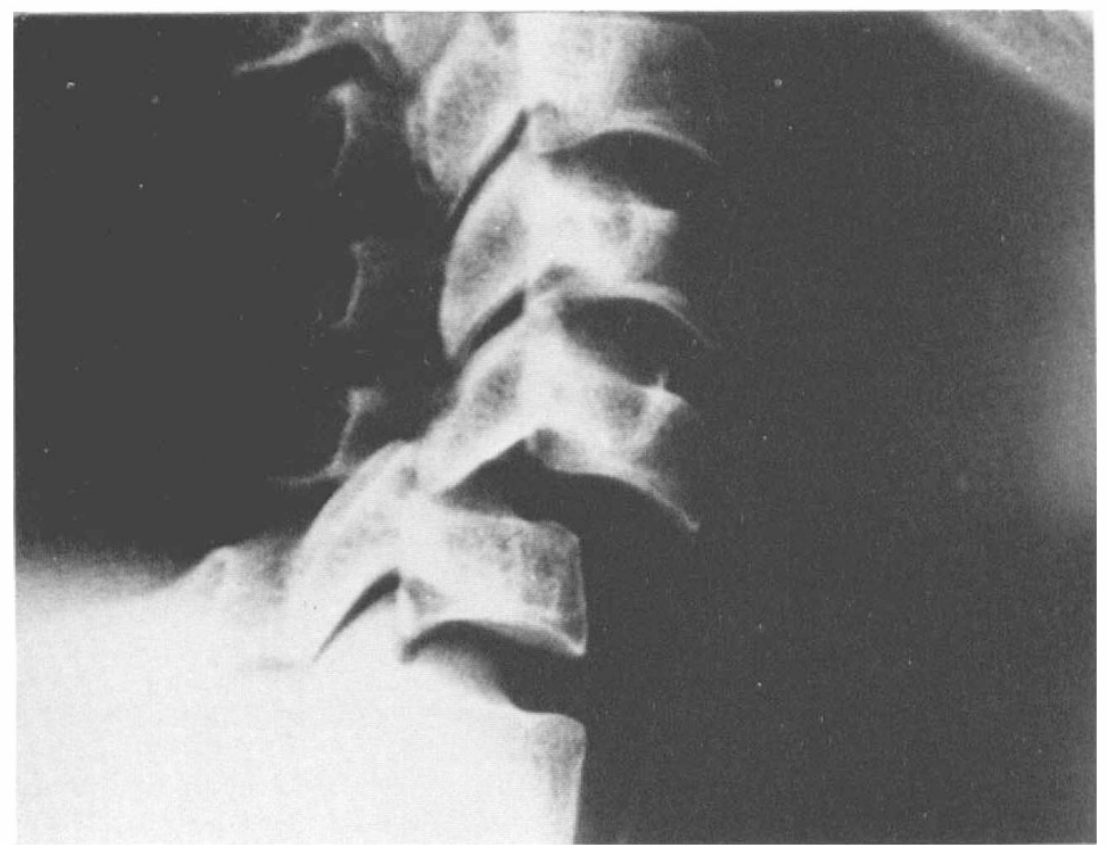

FIG. I

Listhesis of $\mathrm{C}_{5}$ on $\mathrm{C} 6$ with dislocation of the apophyseal joints. Bilateral interlocking of the articular facets is present.

2 reveals listhesis of $\mathrm{C}_{5}$ on $\mathrm{C}_{6}$ with unilateral dislocation and interlocking of the facets of the apophyseal joints.

\section{Materials}

From January I976 to December I980, IOI patients were admitted with dislocation or fracture-dislocation of the cervical spine, all with neurological involvement. The degree of neurological involvement and level of dislocation is set out in Table I. Complete tetraplegia on admission was defined as the complete absence of motor and sensory functions below the level of the lesion on clinical examination. Incomplete tetraplegia was defined as the presence of some neurological function below the level of the lesion on examination. By these criteria, 56 had complete tetraplegia and in 45 the neurological involvement was incomplete.

\section{Methods}

The following is the routine management that was employed: On admission an accurate general assessment is made. A neurological examination is carried out as well as the appropriate radiological investigation. The patient is put onto a pack bed and is lifted two-hourly by a trained turning team. Skeletal traction is applied in the ward under local anaesthesia. We prefer Crutchfield tongs as they are easily applied and do not interfere with the positioning of the patient in the lateral position. Occasionally use 


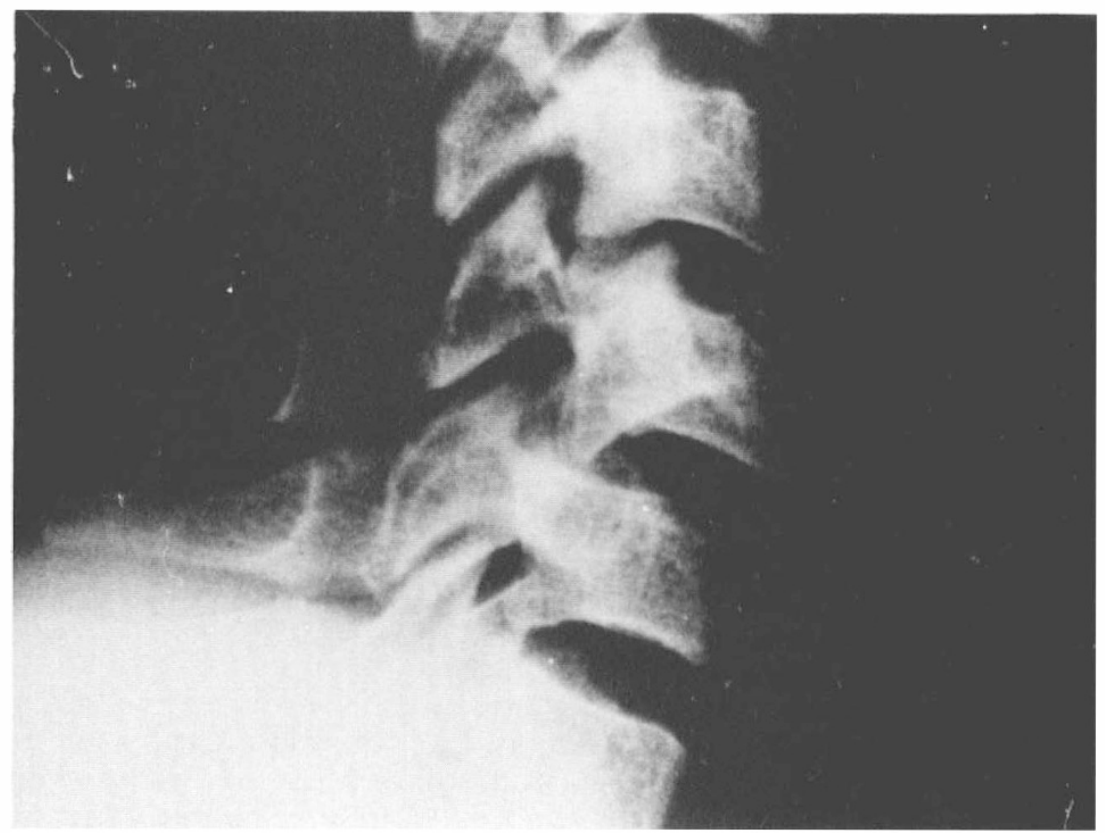

FIG. 2

Listhesis of $\mathrm{C}_{5}$ on $\mathrm{C} 6$ with unilateral dislocation and interlocking of the facet of the apophyseal joints.

is made of Cone's Calipers, when the site of lacerations of the scalp precludes the use of Crutchfield tongs. Traction with $5 \mathrm{kgs}$ is applied initially.

When the dislocation is of less than 24 hours duration, closed reduction under anaesthesia is attempted. If the injury is more than 24 hours old, only increasing traction is applied initially; the weight is increased by 2 kgs half-hourly with X-ray control and under the supervision of the medical attendant. A maximum of $15-18 \mathrm{kgs}$ is applied, depending on the general condition of the patient. If the dislocation fails to reduce, closed reduction under anaesthesia is attempted.

The following is our routine for closed reduction: The patient is taken

TABLE I

\begin{tabular}{lrcc}
\hline Dislocation & No. & $\begin{array}{c}\text { Incomplete } \\
\text { lesions }\end{array}$ & $\begin{array}{c}\text { Complete } \\
\text { lesions }\end{array}$ \\
\hline C2-3 & 2 & I & I \\
C3-4 & 6 & 2 & 4 \\
C4-5 & 30 & I 4 & I6 \\
C5-6 & 34 & I9 & I 5 \\
C6-7 & 23 & 8 & I 5 \\
C7-T I & 6 & I & 5 \\
Total & IOI & 45 & 56 \\
\hline
\end{tabular}


to the operating theatre on the pack bed. To facilitate transfer of the bed to the theatre, a specially designed undercarriage was manufactured with larger wheels than those of a conventional hospital bed. Unnecessary transfers are thus avoided and constant skeletal traction is maintained, which is not always possible on a theatre trolley. It is important to apply traction in a neutral position or slight flexion, but not in extension while the cervical spine is still dislocated. In the theatre the image intensifier is used to monitor the reduction. Light Penthothal anaesthesia is used with a shortacting relaxant (Scoline). Intubation is not done as a routine, but all the necessary equipment is kept in readiness in case the anaesthetist requires it. Extension of the dislocated cervical spine must be avoided during intubation.

When the patient is completely relaxed, closed reduction is attempted. Two assistants hold the shoulders and upper arms to apply counter traction. Standing to the left of the anaesthetist, the orthopaedic surgeon holds the head with one hand under the chin and the other behind the occiput. Weights are then released while Crutchfield tongs remain in situ. Increased traction in the neutral position is applied under control of the image intensifier. Often a click or thump can be felt as the dislocation is reduced. If the reduction is successfully achieved, the patient is lifted by the turning team with the head suspended. A pillow is placed under the shoulders and the traction is re-applied with the neck now in extension. Control left and right sided lateral $\mathrm{X}$-rays are taken to confirm the reduction of the dislocation.

If reduction is not achieved, further manoeuvres may have to be attempted: first, rotation with increased traction, then lateral traction with the assistant applying increasing traction on the arm on the opposite side.

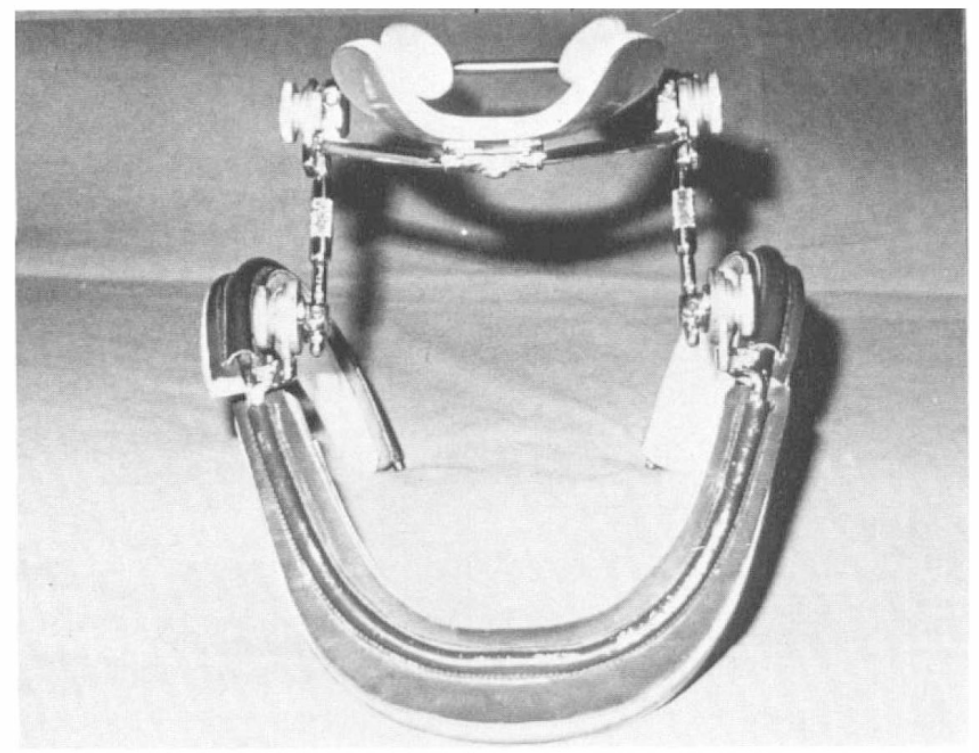

Fig. 3

Bio-con Cervical collar. 


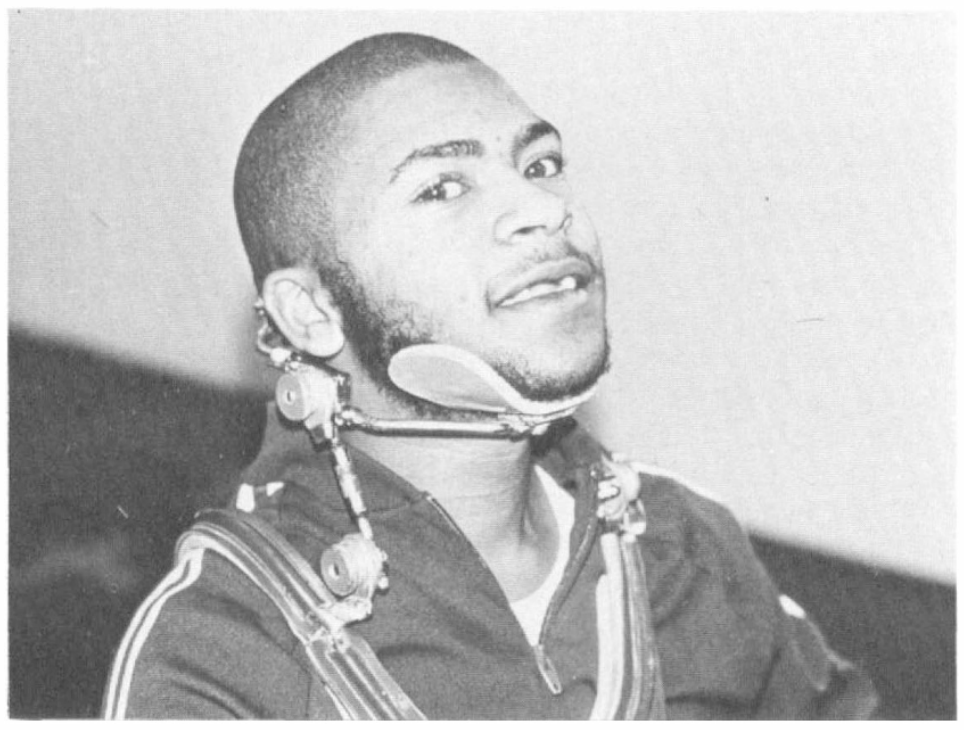

FIG. 4

Bio-con collar fitted to patient.

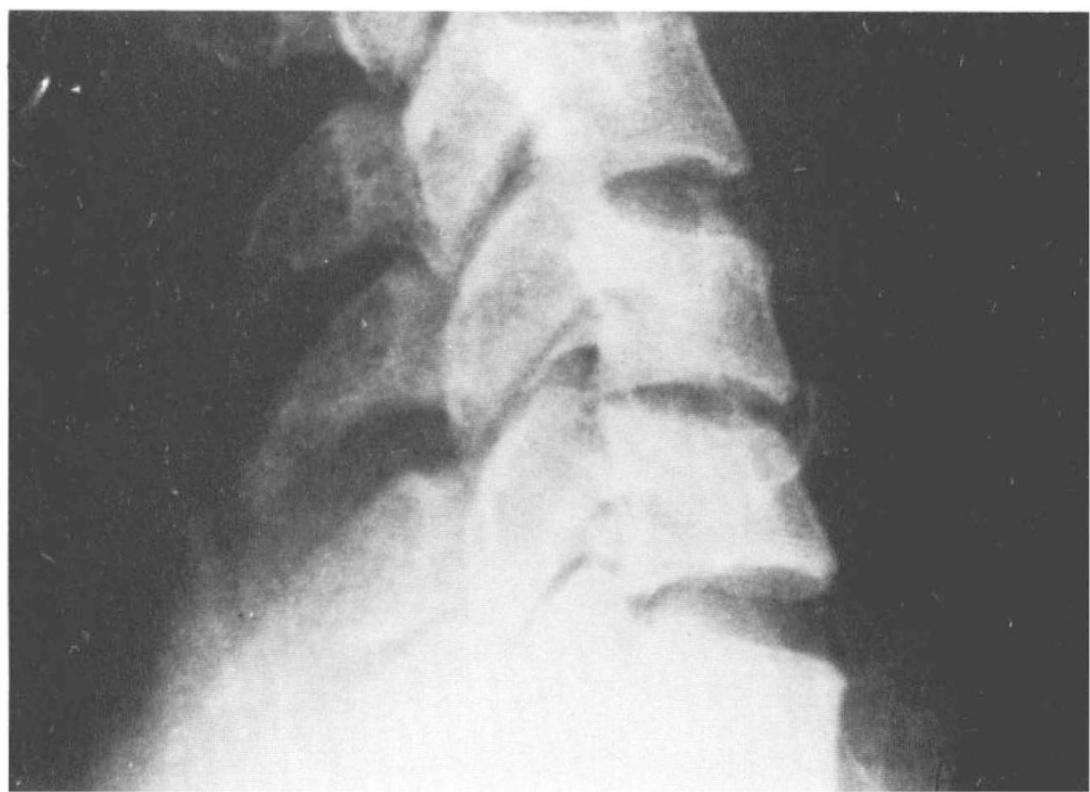

FIG. 5

Lateral view of a reduced cervical spine still in extension after three months immobilisation.

If reduction is still unsuccessful and the general condition of the patient is satisfactory, an open reduction, wiring and spinal fusion is performed using the posterior approach. 
After reduction, immobilisation on a pack bed is maintained for 12 weeks, during which time the routine tetraplegic care of joints, skin and the urinary system is maintained. Routine neurological assessments are carried out to detect any improvement or deterioration; and routine lateral radiographs are taken at 3 weeks and 6 weeks. Flexion and extension lateral radiographs are taken to assess stability at 12 weeks.

In the early years covered by this review, the decision for or against fusion was taken at 12 weeks. If the lesion was found to be radiologically stable at that stage, the patient was allowed up. For the first 6 weeks out of bed the neck was supported in a Bio-con Cervical Collar (Abrahams and Shrosbree, I979-1980) by day (Figs. 3 and 4) and in a soft sorbo collar at night. If the spine was found to be unstable at 12 weeks (Figs. 5 and 6), a delayed posterior fusion with wiring was done at that stage (Fig. 7). In more recent years we have tried to anticipate instability in the 6-week neutral radiograph. At that stage we looked for widening of the interspinous gap, listhesis of the vertebral body, widening of the disc space posteriorly and forward subluxation of the articular facets as is seen in Figure 8. This appearance was the indication for posterior fusion at that stage.

\section{Results}

Eighty-two out of IOI dislocations were completely reduced by the closed method. Failure of closed reduction was immediately followed by open

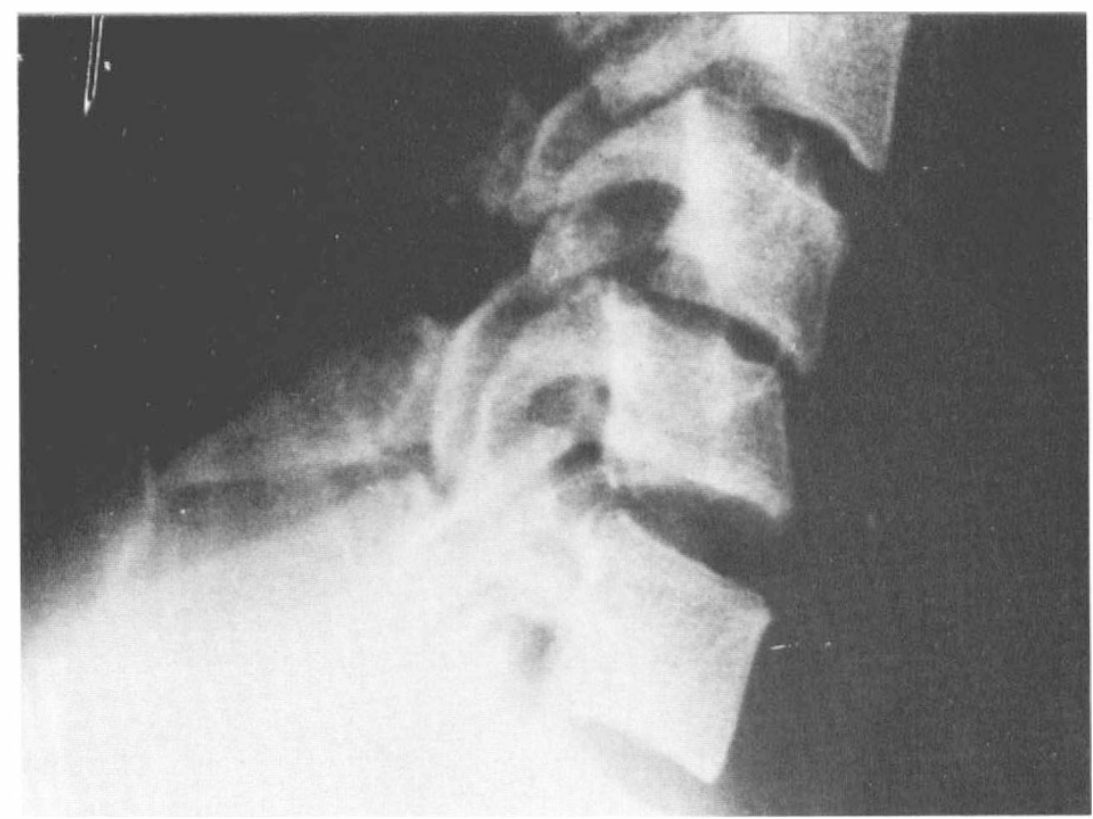

FIG. 6

Lateral view cervical spine in flexion at 12 weeks reveals listhesis of $\mathrm{C}_{5}$ on $\mathrm{C} 6$ with widening of the posterior spinous processes and subluxation of the apophyseal joints. 


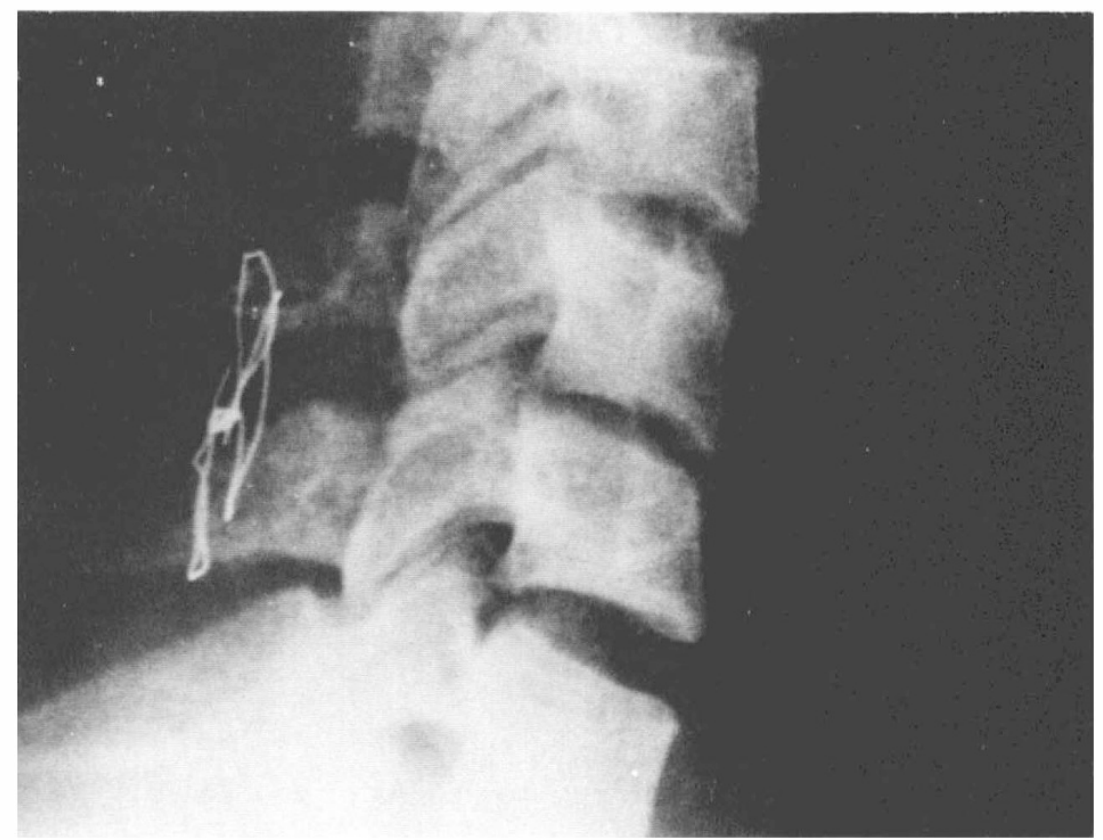

FIG. 7

Lateral view cervical spine after posterior cervical fusion with wiring of posterior spinous processes.

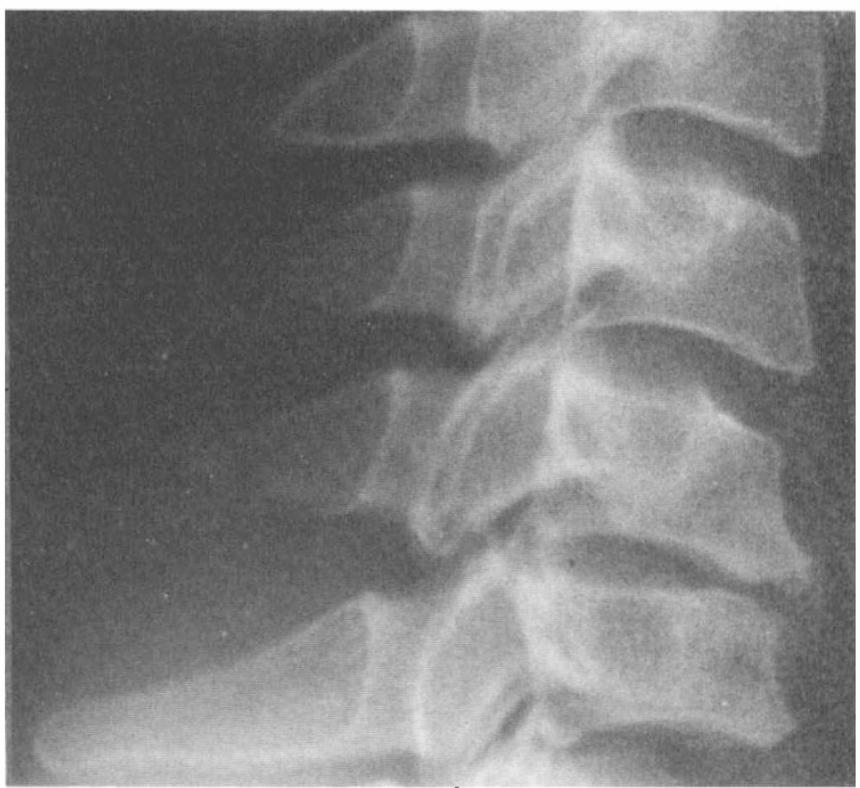

FIG. 8

6-week neutral lateral radiograph. 
TABLE II

The 6-month neurological outcome of 56 patients with complete tetraplegia. Of the Io deaths recorded, all occurred after the fourth day and none was attributed to anaesthetic complications. See text.

\begin{tabular}{lcccc}
\hline & \multicolumn{2}{c}{$\begin{array}{c}\text { Unilateral } \\
\text { locked facets }\end{array}$} & \multicolumn{2}{c}{$\begin{array}{c}\text { Bilateral } \\
\text { locked facets }\end{array}$} \\
\cline { 2 - 5 } & $\begin{array}{c}\text { Admitted } \\
\text { within } \\
\text { 24 hours }\end{array}$ & $\begin{array}{c}\text { Admitted } \\
\text { after } \\
\text { 24 hours }\end{array}$ & $\begin{array}{c}\text { Admitted } \\
\text { within } \\
\text { 24 hours }\end{array}$ & $\begin{array}{c}\text { Admitted } \\
\text { after } \\
\text { 24 hours }\end{array}$ \\
\hline No improvement & 6 & I & 23 & 9 \\
Minimal recovery & 0 & 0 & 2 & 0 \\
Major recovery & 0 & 2 & 2 & I \\
Death & I & 0 & 6 & 3 \\
Total & 7 & 3 & 33 & 13 \\
\hline
\end{tabular}

TABLE III

The 6-month neurological outcome of 45 incomplete lesions. See text.

\begin{tabular}{lcccc}
\hline & \multicolumn{2}{c}{ Unilateral } & \multicolumn{2}{c}{$\begin{array}{c}\text { Bilateral } \\
\text { locked facets }\end{array}$} \\
\cline { 2 - 5 } & $\begin{array}{c}\text { Admitted } \\
\text { within } \\
\text { 24 hours }\end{array}$ & $\begin{array}{c}\text { Admitted } \\
\text { after } \\
\text { 24 hours }\end{array}$ & $\begin{array}{c}\text { Admitted } \\
\text { within } \\
\text { 24 hours }\end{array}$ & $\begin{array}{c}\text { Admitted } \\
\text { after } \\
\text { 24 hours }\end{array}$ \\
\hline No improvement & 2 & 5 & I & 0 \\
Minimal recovery & 2 & I & 0 & 0 \\
Major recovery & IO & 7 & 4 & 4 \\
Full recovery & 5 & 3 & I & 0 \\
Death & 0 & 2 & I & 0 \\
Total & I9 & I8 & 7 & 4 \\
\hline
\end{tabular}

reduction in a further four patients. In six patients bilateral locked facets were partly reduced to unilateral locked facets and this state was accepted. In the remaining nine, failure of closed reduction was accepted and no open reduction performed because of the poor general condition of the patient. Seventeen patients had posterior fusion and wiring for radiologically demonstrable instability at 12 weeks, and a further six patients were fused at 6 weeks for the reasons set out in the previous paragraph. The neurological state was assessed 6 months after injury, and is presented on Tables II and III. By a complete lesion on admission this meant a total loss of all sensory and motor functions below the level of the lesion. In incomplete lesions, some sparing was present on admission. By 'major recovery' we mean that full or diminished sensory recovery has occurred with a useful degree of motor recovery. By 'minimal recovery' is meant a non-functional motor recovery and/or patchy sensory recovery. It is noteworthy that no patients' neurological state deteriorated. Further, some 
degree of neurological recovery was recorded in seven out of 56 complete lesions and in 37 out of 45 incomplete neurological lesions.

Despite an air-service and appeals for immediate referral of Spinal Cord injuries, 36 patients reached us more than 24 hours after the time of the accident. This is attributed partly to the large referral area ( $\mathrm{I}, 200 \mathrm{~km}$ radius) and partly to failure to recognise the seriousness of the injury. Tables II and III analyses the neurological outcome of the early admissions against that of the late admissions. No statistically valid conclusions can be drawn, but it does not seem as if the duration of the lesion materially influenced the neurological recovery rate. Looking specifically at the 16 total tetraplegics admitted after 24 hours, two out of three with unilateral locked facets and one out of 13 with bilateral locked facets exhibited major neurological recovery (Table II).

\section{Discussion}

Our major misgiving when undertaking closed reduction under anaesthesia was that the neurological damage might be made worse. Tables II and III show that 44 had improvement in their neurological status and none deteriorated. Our results have convinced us that careful reduction under radiological control does not cause further neurological damage. It must be emphasised that we have not used the methods of reduction advocated by Burke and Berryman (1971) and Evans (1983). Increased traction under a short-acting muscle relaxant, without intubation while the head is kept neutral or slightly flexed, are all essential ingredients of an easy, quick and atraumatic reduction. Some controversy still exists regarding the need for early surgical fusion. We have done early fusion only in those cases (four in all) in whom early open reduction was necessitated by failure of closed reduction. Of the 82 successful closed reductions, we did delayed fusion on a total of 23 when instability was found at 6 to 12 weeks. None of the patients who did not have spinal fusion have returned with late instability. We now recommend fusion in the minority of cases in whom instability is demonstrated on the 6-week non-stressed lateral radiograph by widening of the interspinous distance, minor listhesis of the vertebral body, widening of the posterior disc space or subluxation of the facet joints (Fig. 8).

Death occurred in 13 patients. None died in the first 3 days after reduction. Six deaths occurred at 4-7 days, four occurred during the second week and three occurred after the end of the second week. No death was attributable to post-anaesthetic complications; death was due to respiratory failure and cardio-vascular dysfunction.

It is worth considering the value of reducing the cervical dislocation in complete tetraplegics admitted later than 24 hours after injury. Neurological improvement in two out of three such patients with unilateral locked facets and one out of I 3 with bilateral locked facets encourage us to recommend reduction of all such dislocations, even when admitted after 24 hours (Shrosbree, I979-1980).

This series has no controls; we have no data on what happens if the dislocation is left unreduced. It is probable, however, that local pain and deformity could cause on-going disability in addition to the possible reduced likelihood of neurological recovery. 


\section{Summary and Conclusions}

I. Careful closed reduction of cervical dislocations with neurological involvement is a safe and effective form of management.

2. No patients' neurological state was made worse and 44 out of IOI showed a greater or lesser degree of improvement.

3. Early posterior fusion with wiring is recommended only occasionally. In our IOI patients, it was performed four times, necessitated by failure of closed reduction.

4. Fusion is not always necessary: delayed fusion may be performed at 6 weeks when an unstressed lateral radiograph shows widening of the interspinous distance, minor listhesis, widening of the posterior disc space or subluxation of the facet joints.

5. A flexion radiograph at 12 weeks may yield more convincing evidence of instability which is an indication for posterior fusion with wiring at that stage. In our series of IOI patients, only 23 came to fusion at 6 or I 2 weeks.

6. This series demonstrated neurological improvement in three out of 16 patients admitted over 24 hours after injury with complete tetraplegia on admission. On this basis, reduction of the dislocation is recommended even after a delay of 24 hours or more.

\section{Acknowledgements}

I wish to thank the Medical Superintendent of the Conradie Hospital for permission to publish this article and the medical, nursing and paramedical staff for their assistance in the treatment of these patients. My special thanks to Professor A. W. B. Heywood, who gave me the necessary encouragement, assistance and advice.

\section{RÉSUMÉ}

Ce papier passe en revue les cas de IOI malades qui souffraient de luxation soit de fracture-luxation de la vertèbre cervicale avec implication neurologique, qui ont été traités par réduction fermée sous anesthésie. On les a tous admis à une unité spécialisée où une diagnose prompte et précise a été suivie de l'application de pinces Crutchfield et d'une tentative, effectuée sans tarder, de réduction fermée.

Sur les IOI malades ainsi traités, on a effectué une réduction complète chez 82 . Une réduction partielle a été obtenue chez 6 malades. On a effectué une réduction à ciel ouvert et une arthrodèse postérieure sur 4 malades à la suite d'une réduction fermée qui n'a pas réussi. On n'a pas tenté une réduction à ciel ouvert chez 9 malades à cause de leur pauvre condition générale. Vingt-trois malades ont reçu une arthrodèse retardée à cause de l'instabilité radiologiquement démontrée à une période entre 6 semaines et 12 semaines.

Sur less 56 malades qui souffraient de lésions complètes, 5 ont montré un rétablissement neurologique après 6 mois, et il y a eu Io morts à des périodes qui allaient de 4 à 25 jours après la blessure. Sur les 45 malades qui souffraient de lésions incomplètes, 6 ont fait preuve d'un rétablissement clinique complet, 28 ont fait preuve d'un rétablissement majeur, et il y a eu 3 morts à des périodes de 9 à I 4 jours après la blessure. Nos résultats nous amènent à croire que la méthode est sûre et fiable, même chez les malades reçus plus de 24 heures après la blessure.

\section{ZUSAMMENFASSUNG}

Dieser Vortrag enthält eine Durchsicht von Io I Pazienten mit Luxation bzw. FrakturLuxation des Halswirbels zusammen mit neurologischer Beteiligung, die durch geschlossene 
Frakturreposition unter Anästhesie behandelt worden sind. Alle sind in einer spezialisierten Einheit aufgenommen worden, wo einer frühen, genauen Diagnose die Anwendung von Crutchfield-Zangen und ein früher Versuch, eine geschlossene Frakturreposition auszuführen, folgten.

Von den IOI so behandelten Pazienten, haben 82 eine vollkommene Frakturreposition erfahren. Man hat eine teilweise Frakturreposition bei 6 Pazienten erreicht. Ferner hat man eine offene Frakturreposition und eine hintere chirurgische Wirbelvereinigung auf 4 Pazienten nach einer misslungenen geschlossenen Frakturreposition ausgeführt. Bei 9 Pazienten hat man doch keine offene Frankturreposition wegen ihres schwachen allgemeinen Zustands versucht. Dreiundzwanzig Pazienten haben eine verzögerte chirurgische Wirbelvereinigung gehabt, und zwar wegen Unbestädigkeit, die zwischen 6 und 12 Wochen radiologisch bewiesen worden ist.

Von den 56 Pazienten mit vollkommenen Verletzungen, haben 5 eine neurologische Genesung nach 6 Monaten erwiesen, und es sind Io Todfälle an Zeitpünkten von 4 bis 25 Tagen nach der Verletzung gewesen. Von den 45 Pazienten mit unvollkommenen Verletzungen, haben 6 eine vollkommene klinische Genesung und 28 eine bedeutende Genesung erwiesen, und es sind 3 Todfälle von 9 bis 14 Tagen nach der Verletzung gewesen.

Unsere Ergebnisse lassen uns glauben, dass die Methode sicher und zuverlässig ist, auch bei Pazienten, die mehr als 24 Student nach der Verletzung aufgenommen worden sind.

\section{REFERENCES}

Abrahams, D. \& Shrosbree, R. D. (1979-80). Stabilisation of the cervical spine using a bio-con collar. Paraplegia, 17, $192-197$.

BURKE, D. C. \& BERRYMAN, D. (197I). The place of closed manipulation in the management of flexion-rotation dislocations of the cervical spine. F. Bone E foint Surg. 53B, $165-182$.

CRUtChField, W. G. (1954). Skeletal traction in treatment of injuries to the cervical spine. fournal of the American Medical Association, 155, 29.

Evans, D. K. (1983). Dislocations at the cervicothoracic junction. F. Bone foint Surg. (Br), 65-B, $124-127$.

GutTMANN, SIR L. (1973). Spinal Cord Injuries. Blackwell Scientific Publications 126-133.

KEY, A. (1975). Cervical spine dislocations with unilateral facet interlocking. Paraplegia, 13, 208-215.

SCHER, A. T. (1980). Dislocation, subluxation or listhesis? S. Afr. Med. F., 57, 132.

SHROSBREE, R. D. (1979-I 980). Neurological sequelae of reduction of fracture-dislocations of the cervical spine. Paraplegia, 17, 212-221. 